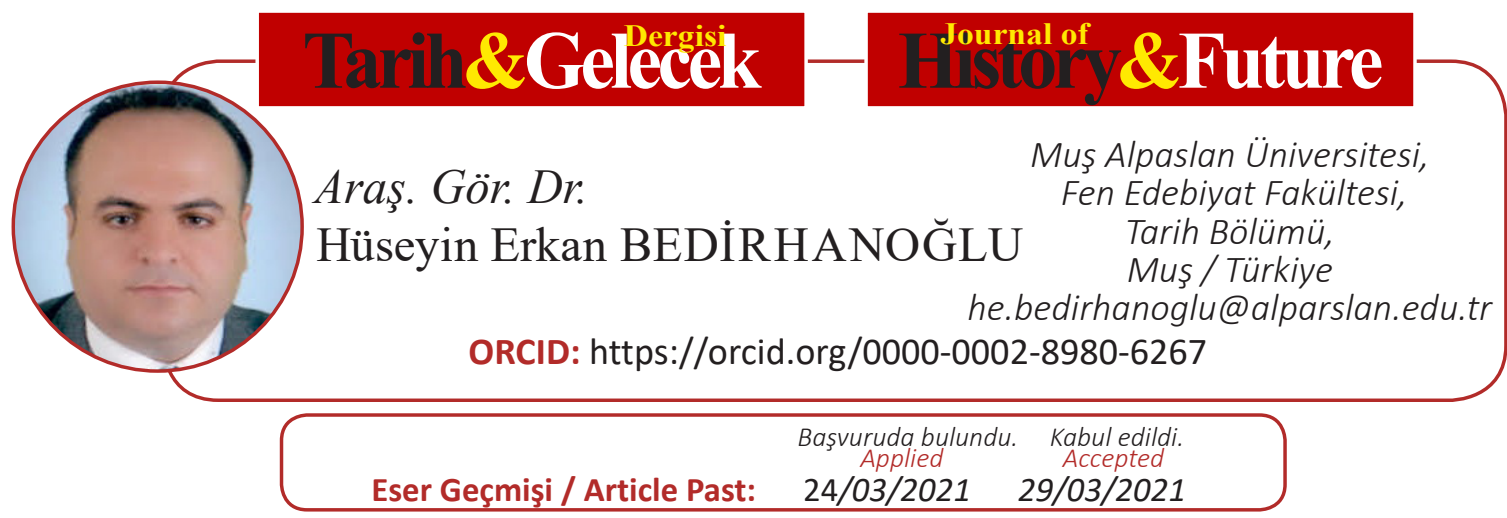

Araştırma Makalesi

DOI: http://dx.doi.org/10.21551/jhf.902626

Research Paper

Orjinal Makale / Original Paper

\title{
Anadolu'yu İlk İmar Edenler: Fethin Asıl Sahipleri
}

\author{
The First Builders of Anatolia: Conquest's Real Owners
}

\section{$\ddot{\mathbf{O} z}$}

Alparslan'1n Malazgirt Zaferinden sonra Anadolu'da fetih yapmakla görevlendirmiş olduğu kabul edilen bazı önemli şahsiyetlerin, Anadolu'ya geldikten ve müstakil bağımsız beyliğini/devletini kurduktan sonra, periferide yer alan dönemin önemli güçleriyle her alanda yaşadıkları siyasi süreçler ve bu süreçlerde takındıkları tavır ve aldıkları rol, dönemin bazı şahıs ve devletlerinin maalesef gölgesinde kalmıştır, bırakılmıştır. Tartışmalar popüler olay ve kişiler üzerinden yürümüş/ yürütülmüştür. Ancak çalışmamıza konu olan, Anadolu'nun fethinde bir şekilde bulunmuş olan, kişilerin motivasyonu salt bir fetih görevlendirmesiyle gerçekleşmiş olamaz. Fetih sonrası hayata geçirilen bürokratik ve yönetimsel başarı da alelade bir komutan/ bey/ gazi olmakla açıklanacak bir durum değildir. Nitekim bu kişilerin coğrafyada meydana gelen en küçüğünden en büyüğüne bütün hadiseler ile doğrudan ilişki içerisinde bulunmaları da göz ardı edilmemelidir. Malazgirt bütün karanlık yönlerine rağmen bir dönüm noktasıdır, ancak bir vatan ve ülkeden bahsedilecekse eğer, bu beylerin yararlılıklarının Malazgirt ve Alparslan'dan geri kalır bir yanı yoktur, olmamalıdır. Bu çalışmada bahsi geçen müstakil beyliklerin üstlendikleri siyasi roller ile Anadolu'nun siyasal imarına olan katkıları değerlendirilmiştir.

Anahtar Kelimeler: Malazgirt, Alparslan, Artuk, Danişmend, Mengücek, Çaka

\section{Abstract}

After Alparslan's Malazgirt Victory, some important personalities, who were accepted to have conquered Anatolia, came to Anatolia and established their independent independent principality / state, the political processes they lived in every field with the important forces of the period in the periphery and the attitude and attitude they took in these processes. Unfortunately, the role was overshadowed by some individuals and states of the period. Discussions were carried out on popular events and people. However, the motivation of the people who were the subject of our study, who were found in the conquest of Anatolia, could not have been realized solely by assigning a conquest. The bureaucratic and managerial 
success achieved after the conquest is not something that can be explained by being an ordinary commander / bey / veteran. As a matter of fact, it should not be ignored that these people have a direct relationship with all events, from the smallest to the largest, in the geography. Malazgirt is a turning point in spite of all its dark aspects, but if a country and a country are to be mentioned, the usefulness of these gentlemen is nothing less than Malazgirt and Alparslan, it should not be. In this study, the political roles undertaken by the aforementioned independent principalities and their contribution to the political development of Anatolia were evaluated.

Key Words: Malazgirt, Alparslan, Artuk, Danişmend, Mengücek, Çaka

\section{Giriș}

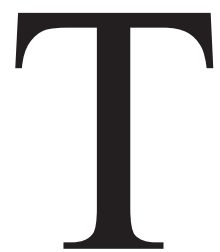

ürklerin, Anadolu'ya sefer düzenlemeleri ve fethetme girişimleri 11.yüzyılda başlamış ve 15.yüzyılın ortalarına kadar süregelmiştir. Türklerin, Anadolu’ya yerleşmeleriyle birlikte, birçok konuda köklü değişmeler meydana gelmiştir. Büyük Selçuklu Devleti kurulmadan önce, Abbasilerin hizmetindeki Türkler, Anadolu'ya seferler düzenlemişlerdi. En önemli fetihler ise 1040’ta Horasan'da kurulan Büyük Selçuklu Devleti zamanında olmuştur. Selçukluları, kuruluşundan itibaren uğraştıran en önemli sorunlar, yurt ve sürülerini beslemek için geniş kışlak ve yaylaklar bulmaktı. Anadolu bunun için en uygun yerdi. Türkler, hem kendi ihtiyaçlarını hem de Bizans'a karşı cihat görevini yerine getirmek için Anadolu'yu fethetmeye başladılar' ${ }^{1}$. Bu sayede hem Türklere yurt bulunuyor hem de Bizans'a karşı kuvvet kazanılıyordu².

Selçuklu Devleti’nin kurulduğu günden Malazgirt Zaferinin kazanılmasına kadar süren bu akınlar ve göçler Bizans’ın gücünü zayıflatmıştır. Türklerin başlattığı bu fetih hareketleri sayesinde, Anadolu'nun birçok bölgesine yayılma imkânı sağlandı. Fakat Bizans'ın sürekli yaptığı baskınlar Türklerin, Anadolu'da güvenle oturmalarına izin vermiyordu.

Malazgirt Savaşı'nda, Bizans’ın yenilmesi üzerine, Anadolu kapıları Türklere açıldı. Bundan sonra büyük çapta Anadolu’ya Türk göçleri başladı. Bizans bu yoğun göçler karşısında Doğu ve Orta Anadolu'dan, Batı Anadolu ve Balkanlara çekilmek zorunda kalmıştır.

Malazgirt Zaferinden sonra (1071) Anadolu topraklarında ilk Türk devlet ve beylikleri de kurulmaya başladı. Savaştan sonra Alp Arslan, önemli komutanlarını Anadolu fethine tayin etti. Bu komutanlar Anadolu'nun her tarafında fatihler yapmaya başladılar. Bu komutanlar, ele geçirdikleri topraklarda kendi adlarını verdikleri devletler kurdular. Kurulan bu devletler, kültür, din, gelenek, görenek gibi kendi unsurlarını yaşayarak Anadolu da köklü değişmelere neden oldular. Anadolu'ya gelen bu insanların ruhundaki savaşma hissi ve cihat anlayışı onları sürekli savaş yapmaya sevk etmiştir. Bununla beraber sınırlar da sürekli genişlemiştir. Genişleyen sınırlarla birlikte, Bizans'la olan anlaşmazlıkların yanında, kendi aralarında da anlaşmazlıklar çıkmaya başlamıştır. Çıkan bu anlaşmazlıklar, Anadolu’da Türk birliğin sağlanmasını geciktirmiştir.

1 Muhammed Şahin, Türk Tarihi ve Kültürü, Ankara 1999, s. 83.

2 Osman Turan, Selçuklular Tarihi ve Türk-İslam Medeniyeti, İstanbul 2011, s. 277. 


\section{A - Artuk Bey}

Oğuzların Döğer boyuna mensup olan Artuk Bey’in doğumu hakkında bilgi bulunmamaktadır³. Mensup olduğu topluluk hakkında kaynakların hepsi de aynı bilgiyi vermektedirler. Örneğin; "Oğuzların Döğer ya da Kınık boyundan olan Artuk b. Eksuk", "Oğuzların Kayı Boyu beylerinden Eksuk Beyin oğludur”, Oğuzların Döğer boyundan olup ünlü bir Türkmen Beyidir6 . 1060 yılanda kendisine bağlı Türkmenlerle Alparslan'ın hizmetine girdi ve Malazgirt'te, sultanın büyük bir destekçisi olduํ. Bu savaştan sonra Alparslan'ın emri ile Anadolu'ya gelerek, Bizans'a karşı büyük başarılar elde etti ${ }^{8}$.

Orta Anadolu' da fetihler yaptıktan sonra, İzmir taraflarına ulaştı. Sultan Melikşah döneminde (1072-1092) İzmit'e kadar gelen Artuk Bey, Bizans’taki iç mücadelelere karışmıştır9. Selçuklu şehzade ve emirleriyle birlikte Bizans'a karşı isyan edip İstanbul'a saldıran Norman komutanı Urselius'un etkisiz hale getirilmesi konusunda Bizans'tan gelebilecek yardımla Urselius'u yenilgiye uğratmayı başard1 ${ }^{10}$. Bu başarı sebebiyle Melikşah, Artuk Bey’e Hülvan'1 verdi ve Karmatilerin egemenlik altına alınmasıyla görevli kıld ${ }^{11}$. Selçuklu ordusunun kumandanı Fahruddevle ile çıkan gerginlik Artuk Bey'in, Melikşah ile arasının açılmasını sağlamış ve Artuk Bey bu sebeple Suriye Selçuklu hükümdarı Tutuş ile yakınlaşmıştır ${ }^{12}$. Tutuş, Artuk Bey’i Kudüs'e vali olarak tayin etmiş, Serhad şehrini de kendisine ikta olarak verdi $(1085)^{13}$.

Süleyman Şah, Halep'i kuşatması üzerine, Tutuş, yanına Artuk Beyi de alarak Halep'e geldi. Böylece iki Türk ordusu şiddetli bir savaş yaşanmıştır. Sonuçta Artuk Bey’in desteklediği Tutuş kazanmıştır. Süleyman Şah bu yenilgiye dayanamayarak intihar etti (5 Haziran 1086) ${ }^{14}$. Bu savaştan sonra Artuk Bey, vali olarak bulunduğu Kudüs'e giderek ölünceye kadar orada kalmıştır (1086) .Artuk Bey'in ölümünden sonra oğulları İlgazi ve Sökmen onun yerine geçtiler. ${ }^{15}$ Kudüs'ün 1098 yılında Fatimilerin eline geçmesi üzerine Artuklular, Diyarbakır taraflarına çekilmek zorunda kaldılar. Bu bölgeye gelen Artuklular, Hısın Keyfa (Hasankeyf), Mardin ve Harput olmak üzere üç ayrı beylik halinde varlıklarını devam ettirdiler.

Hısn Keyfa Artukluları (1102-1232), Artuk Bey’in 5 oğlundan biri olan Sökmen Bey’dir. Kurucusundan dolayı bu kola Sökmenliler de denilmektedir ${ }^{16}$. Cezire emiri Çökürmüş ve Musul hakimiyeti konusunda Türkmen Musa ile yaşadığı sıkıntı sebebiyle Türkmen Musa Sökmenden

\footnotetext{
3 Ali Sevim, “Artuk b. Eksuk”, Türkiye Diyanet Vakfi İslam Ansiklopedisi, Cilt: III., İstanbul 1991, s.414.

4 Mustafa Eren,“Artuk Bey”, Görsel Büyük Genel Kültür Ansiklopedisi, Cilt: III., Ankara 1999, s.858.

$5 \quad$ Yilmaz Öztüna, Büyük Türkiye Tarihi, Cilt: I., İstanbul 1977, s.475.

6 İbrahim Kafesoğlu, “Orta Doğuda Kurulmuş Türk Devletleri”, Türk Dünyası El Kitabı, Ankara 1976, s. 838.

7 Sevim, agm., s. 414.

8 İlhan Erdem, “Doğu Anadolu Türk Devletleri”, Türkler, Cilt: VI., Ankara 2002, s. 385.

9 Erdoğan Merçil, Müslüman - Türk Devletleri Tarihi, Ankara 2011, s. 243.

10 Sevim, agm., s. 415.

11 Erdem, agm., s.243.

12 Merçil, age., s. 243.

13 Sevim, agm., s. 414.

14 Sevim, agm., s. 4.

15 Merçil, age., s. 243.

16 Öztüna, age., s. 474.
} 
yardım istedi ve bu yardım bedeli olarak Hısn Keyfa ve 10 bin dinar vermeyi taahhüt etti. Bu destek sayesinde Türkmen Musa, Çökürmüş’ü bozguna uğrattı ancak kısa sure sonra kendisi de öldürüldü. Sökmen ise Hısn Keyfa'ya giderek şehri teslim aldı ve Aruklular'ın buradaki şubesini $\mathrm{kurdu}^{17}$.

Sökmen, Sultan Tapar'a bağlılık bildirdi ve Diyarbakır'ın büyük bir bölümünü ele geçirdi. 1104 'de ölünce yerine oğlu İbrahim geçti. O da 1108'de ölünce diğer oğlu Rükneddin Davut başa geçti. Davut önce Harput ve Palu civarını daha sonra da Siirt ve çevresini ele geçirdi (1131). Yerine oğlu Fahredin Kara Arslan geçti. Daha sonra sırasıyla, Nureddin, Muhammed, Mahmut ve Mevdüd başa geçtiler. Mevdüd döneminde Eyyubi Hükümdarı Me-kikü'1-Kamil, Amid ve Hısın Keyfa'yı alarak Artuklular'ın bu şubesini ortadan kaldırdı (1231) ${ }^{18}$.

Artuk'un oğlu İlgazi, 1108'de Mardin'i ele geçirdi ve 1122'de Halep halkının dileğiyle buraya da egemen oldu' ${ }^{19}$. Irak Selçuklu Sultanı Mahmut, 1121 yılında İlgazi’nın, Gürcülere karşı yaptı̆̆ 1 seferden dolayı kendisine Meyfarikin (Silvan)'i ikta olarak verdi. İlgazi'nin 1122'de ölümü üzerine oğullarından Timurtaş Mardin'e, Süleyman ise Meyafarikin'e (Silvan) üzerinde hakimiyet kurdu. Timurtaş' $1 n$ 1142'de ölmesi üzerine oğlu Necmeddin Alp başa geçti. Onun da ölmesiyle oğlu Kudbeddin II. İlgazi geçti. II. İlgazi'den sonra oğlu Hüsameddin Yavlak Arslan idareyi ele aldı. Küçük yaşta olduğu için devlet Alp Kuş’un eline geçti. Bu sıralarda Salahattin Eyyubi, Artukluları hakimiyeti altına almak için 1185 Ağustosunda Meyafarikin’i zapt etti.

Yavlak’ın ölmesi üzerine başa gelen Artuk Arslan, Alp Kuş’u yenilgiye uğratarak başa geçti. Artuk Arslan zamanında Artuklular,bir dönem Eyyubilere ve ardından Türkiye Selçuklularına bağlı kaldılar. Daha sonra sırayla oğlu Necmeddin, onun oğlu Muzaffer Kara Arslan ve İsa başa geçtiler. İsa'nın ölümünden sonra yerine geçen oğlu Şıhabeddin Ahmed, Mardin'i Karakoyunlulara teslim etti (1409) ${ }^{20}$. Mardin bu dönemde çok önemli gelişmelere sahne olmuştur. Hatta Mardin'de imar adına olan yapıların önemli bir kısmı Artuklu varlığıdır. Harput Artukluları (1185-1234) Nureddin Muhammed'in 1185'te ölümü üzerine, İmadeddin Ebu Bekir, Harput merkezli Artuklu şubesini kurmuştur $^{21}$. 1234'te Anadolu Selçuklu Sultanı I. Alaattin Keykubat tarafindan yıkıldı1 ${ }^{22}$. Ancak Belek Gazi Dönemi müstakil olarak Artuklu içerisinde ayrı bir önem taşımaktadır. Onun döneminde Harput'ta tesis edilmiş olan siyasi yapılanma, Haçlılara karşı önemli yararlılıklar göstermiştir.

\section{B - Çubuk Bey}

Doğu Anadolu Bölgesi'nde beylik kurmadan önceki çalışmaları hakkında herhangi bir bilgi yoktur. Malazgirt Savaşı'ndan sonra Anadolu’yla bağları kesilmiş bulunan Doğu Anadolu'daki Bizans toprakları, Romanos Diogenes'in komutanlarından Philaretos'a bırakılmıştı. 1085'te Çubuk Bey, bu komutana bağlı topraklarda, Frankopol şanı ile tanınmış olan Normandiyalı Herve'nin savunduğu Harput Kalesi'ni alarak, çevresindeki Eğin (Kemaliye), Arapgir, Çemişkezek kaleleri ile Hanzit adı verilen Palu-Genç bölgesini de Türkmenlere açmış ve burada Hanzit Beyliği'ni kurmuştur. Çubuk Bey, kendisine bir beylik kurduktan sonra, aynı yıl içinde Süleyman Şah’tan

$\begin{array}{ll}17 & \text { Erdem, agm., s. } 386 . \\ 18 & \text { Merçil, age., s. } 244 . \\ 19 & \text { Eren, agm., s. } 858 . \\ 20 & \text { Merçil, age., s. } 246 . \\ 21 & \text { Merçil, agm., s. } 249 . \\ 22 & \text { Eren, agm., s. } 858 .\end{array}$


Antakya'yı almak için girişilen savaşa katılmışsa da, Bezak Savaşı'nda Süleyman Şah'ın tarafına geçerek, Arap kuvvetlerinin yenilmesinde önemli rol oynadı. 1092'de Melikşah'ın emri ile Çubuk, Sadüddevle Gevherayin ile birlikte, Hicaz'ın kontrolü ve Yemen ile Aden'in, alınması işi ile görevlendirilen kuvvetlerle Arabistan'a gitmiştir ${ }^{23}$.

1085 'te Selçuklularca Amid Şahnesi yapılmış. 1092'de ise Selçuklular hesabına Yemen'i fethe gitmiş ve dönememiştir. Beyliği oğlu Mehmet'e kalmıştır²4.

Çubuk'a bağlı boylar batıya doğru göç etmeğe başladılar. Doğuda Germiyan ilinde oturdukları için Germeyanlı diye de anılan bu boylar, XIII. yüzyılın ikinci yarısında Bizans sınırına ulaşarak buradaki savaşlara katılmışlardır. Bu yüzden XIV. yüzyılın başında, Anadolu Selçuklu Sultanlığı'nın yıkılmasından sonra, merkezi Kütahya olmak üzere kurulan Germiyanlı Devleti'nin, Çubuk'a bağlı bir Türkmen boyundan meydana gelindiği ileri sürülmektedir ${ }^{25}$.

\section{C - Danişmend Gazi}

Asıl adı Melik-i Muazzam Danişmend Ahmet Gazi b. Ali et-Türkmanî olarak bilinmektedir. Danişmendnamede, Ali b. Mızrab'ın oğlu olarak doğduğu gerçek isminin Ahmet olduğu, dini ilimlere olan merakı ve iştiyakı sebebiyle kendisine Danişmend denildiği de bilinmektedir ${ }^{26}$. Babası Danişmend Ali Taylu, Harzem'den gelip Danişmend olarak Selçukluların hizmetine girmiştir. Burada muallim, muşavir, diplomat ve atabey olarak hizmet etmiştir. Ali Taylu'nun, kesin olarak ne zaman öldüğü bilinmemekle beraber, İsfahan'da Atabeylik yaparken 1055'lerde öldüğü tahmin edilmektedir ${ }^{27}$.

Babasının yerine geçen Danişmend Gazi, kabilesiyle birlikte Azerbaycan ve Arran civarlarına çekildi. Burada baba mesleğini devam ettirmekle beraber, Hıristiyan memleketlerine de akınlar düzenlemiştir. Alp Arslan, Bizans ve Gürcüler üzerine akın düzenlediği sıralarda, orduya katılıp kılavuzluk etmiştir. Bu seferler sırasında yiğitliği ve akıllılığı sayesinde sultanı kendisine hayran bırakmıştır28.

Malazgirt Savaşı'nda sonucu etkileyecek önerilerde bulunmuştur. Alparslan, savaşla ilgili komutanların görüşlerini sorduğunda Danişmend Gazi, o günün çarşamba olduğunu, bu günü ve yarını silahları hazırlamakla geçirip, zemzemle yıkanmış kefenleri hazırladıktan sonra, cuma günü kâtiplerin, minberlerde "ya rabbi, İslam ordularını Mansur ve muzaffer eyle!" diye dua ettikleri zaman saldırılması gerektiğini söyledi. "Eğer şehitlik mertebesine erişirsek bu ne güzel mükâfat!", "Eğer galip ve muzaffer olursak bu ne büyük başarıdır!" Mealindeki ayetleri okuyarak moral kaynağı olmuştur ${ }^{29}$. Bu savaşın ardından Sivas, Niksar, Elbistan ve Malatya kendisine verilmiştir ${ }^{30}$. Danişmend Gazi, kendisine verilmiş olan Sivas'ı ele geçirdi. Burayı merkez yapıp Malazgirt'ten

23 Agah Sırrı Levent, "Çubuk", Türk Ansiklopedisi, Cilt: XII., Ankara 1964, s. 136.

24 Yılmaz Öztüna, "Devletler ve Hanedanlar”, Türkiye 1074-1990, Cilt: II., Ankara 1989, s. 48.

25 Levent, agm., s. 136.

26 Abdulkerim Özaydın, "Danişmend Gazi”, Türkiye Diyanet Vakfi İslam Ansiklopedisi, Cilt: VIII., İstanbul 1993, s. 467.

27 Sefer Solmaz, “Danişmendliler”, Türkler, Cilt: VI., Ankara 2002, s. 430.

28 İbrahim Tellioğlu, Osmanlı Hakimiyetine Kadar Doğu Karadeniz'de Türkler, Trabzon 2004, s.88

29 Özaydın, agm., s. 468.

30 Tellioğlu, age., s. 89. 
sonra Anadolu'da ilk Türkmen beyliğini kurmuştur ${ }^{31}$. Danişmend Gazi'nin ölümünden sonra yerine oğlu Gümüştegin geçmiştir. Bu dönemde Haçlıların, Sivas üzerine gönderdiği orduları yenmiş ve Akabinde Malatya'yı almıştır. 1105'te ölmesi üzerine Emir Gazi başa geçmiştir. 1134'te kadar devam eden Emir Gazi Dönemi, Türkiye'deki siyasi hâkimiyetin Selçuklulardan, Danişmendliler'e geçtiği bir dönemdir. Bunun bir göstergesi olarak Emir Gazi, damadı İzzeddin Mesut'u Türkiye Selçuklu Sultanı yapmasıdır ${ }^{32}$. Emir Gazi'nin ünü , Bizanslılar, Haçlılar ve Ermenilere karşı kazandığ 1 zaferlerden ileri gelmiştir ${ }^{33}$.

Emir Gazinin 1134'te ölmesi üzerine oğlu Muhammed başa geçti. Muhammed'den sonra 1143 'te Danişmend tahtına Yağıbasan geçti. Batıya yayılma imkanı kolay olmadığı için Yağıbasan, Kuzey’e yöneldi ve Ünye, Bafra, Samsun yörelerinde taarruza başlad1. 1166'ya kadar iktidarda kalan Yağıbasan, ülkenin sınırlarını Malatya, Sivas, Tokat, Niksar, Amasya, Erzurum, Çorum, Ankara, Kastamonu ve Canik havalisine kadar genişletti. Yağıbasan'ın ölümünden sonra beyliğin başına sırasıyla İbrahim (1166-1168), İsmail (1168-1169) ve Zünnun (1169-1174) geçmişlerdir ${ }^{34}$.

Danişmend Devleti, bu durumunu uzun süre koruyamadı. İçeride taht kavgaları, dışarıda Bizans saldırılarıyla yıpranan devlet Kayseri, Sivas ve Malatya kollarına ayrıldı. Anadolu Türk birliğini sağlamak amacıyla Selçuklular, önce Kayseri’yi sonra Sivas'ı en sonda da Malatya'yı ele geçirip Danişmendlilere son verdiler $(1178)^{35}$.

\section{D - Mengücek Bey}

Bir Türkmen beyi olan Mengücek Bey, Mengüceklilerin kurucusudur. Yaşamı ve fetihleri konusunda kesin bilgi yoktur. Horasanlı bir aileden geldiği ve Oğuz beyleri arasında önemli bir yere sahip olduğu sanılmaktadır ${ }^{36}$. Bir başka görüşte, Mengücek Gazi’nin, hangi Oğuz boyundan geldiği tam olarak bilinmemektedir ${ }^{37}$. Mengücek Bey'in hakkındaki bilgiler, edebi eserden çok kitabelerde mevcut olduğu için sınırlı kalmıştır. Mengücek Gazi, Sultan Alparslan'ın komutanlarından biri olup, Malazgirt Savaşı'ndan sonra Artuk, Saltuk ve Danişmend gibi komutanlarla, Anadolu fethine tayin edilmiştir. Anadolu'da Erzincan, Kemah ve Kara Hisar'ın doğu taraflarını alarak burada Mengücek beyliğini kurmuştur ${ }^{38}$. Kemah merkezli kurulmuş olan beylik, etrafı güçlü siyasi yapılara komşuluk düzeyinde yakındır. Bu da siyasi ve askeri hareketlilikten çok istikrarlı ve huzurlu bir ortamın oluşmasına yol açtı. Bu huzurlu ortam sebebiyle diğer Türk beylikleriyle kıyaslandığında daha zengin bir kültüre sahip olmasına yol açmıştır ${ }^{39}$. Mengücek Gazi'nin ölmesiyle devletinin başına oğlu İshak geçmiştir. Bu dönemde Mengücekliler, Danişmendlilerin, baskılarına maruz kalmışlardır. Bunun yanında Artuklu şehzadesi Emir Belek Çubuk beyinin ölümünü firsat bilerek, Kemah üzerinde hakimiyet tesis etmeye çalışmıştır. Belek ve Sultan Tuğrul'un birleşerek Kemah'a

\footnotetext{
31 Özaydın, agm., s. 469.

32 Tellioğlu, age., s. 90.

33 Merçil, age., s. 256.

34 Tellioğlu, age., s. 90.

35 Şahin, age., s.87.

36 Hellmut Fritzsche, "Mengücek Gazi", AnaBritannica Genel Kültür Ansiklopedisi, Cilt: XV.,

37 Imprımatur 1768, s.570. Faruk Sümer, "Mengücekliller", Türkiye Diyanet Vakfi İslam Ansiklopedisi, Cilt: XXIX., Ankara 2004, s.138.

38 Riza Nur, Türk Tarihi, Cilt: IV., İstanbul 1924, s.254.

39 Erdem, agm., s.399.
} 
saldırması üzerine İshak, Bizans'ın Trabzon valisi Konstantin Gabras'tan yardım istemiştir. Mengücekoğlu ve Gabras'a karşı, Melik Gazi ile Tuğrul Bey'in yaptığı ittifak neticesinde iki taraf 1120 yılında Erzincan'ın kuzeyindeki Şiran mevkiinde karşılaştılar, Gabras ve Mengücekoğlu esir düştüler. ${ }^{40}$ Mengücek siyasi hayatında da diğer beyliklerde çokça karşılaşmış olduğumuz bir durum ortaya çıkar. Kurmuş olduğu ittifaklar ve bu ittifaklar ile girişmiş oldukları Haçlı, Bizans ve Ermeni mücadeleleri asıl fethin Malazgirt'ten sonra Anadolu'da tutunma mücadelesi olduğunu ak1llara getirmektedir.

Mengüceklilerin, Erzincan koluna hükmeden Davut, 1 yılında karısı tarafindan yayın kirişiyle boğdurulmuş ve Davut'un Divriği' deki kardeşini çağırarak onunla evlenmiştir. Babasının ölümünden sonra tahta oğlu Fahreddin Behramşah geçmiştir. Bu dönemde Mengücekliler, iktisadi ve kültürel sahada büyük bir ilerleme kaydettiler. Fahreddin Behramşah, toplumda fakir ve düşkünlerin ihtiyaçlarını karşılamada çok cömert davranıyordu. Doğada kalan hayvanların ihtiyaçlarını tedarik etmeyi düşünecek kadar cömert sayılırdı. Bu da aynı zamanda medeniyet noktasında geldikleri konumu göstermesi açısından önem taşır. ${ }^{41}$.Behramşah, 1202 yılında Gürcistan seferi sonucunda esir düşüp, hayatını kaybetmesinin ardından yerine II. Davutşah geçmiş, ancak Alaaddin Keykubad ile yaşamış olduğu gerginlik sonrası Sultan Alaaddin, II. Davutşah'1 yakalayarak, Mengüceklilerin bu bölgedeki hâkimiyetine son verdi (Ekim 1228) ${ }^{42}$

Divriği koluni ilk beyi olan Süleyman'dan sonra yerine oğlu Şahinşah geçmiştir. Şahinşah, II.Kılıçaslan ve Sultan Süleyman Şah'a tabi olarak Hıristiyanlarla mücadele etmiştir ${ }^{43}$. Şahinşah'ın ölümünden sonra yerine sırasıyla oğulları Süleyman, İshak ve torunu Ahmet geçmiş, Ahmet'in 1243 'te ölmesi üzerine Melikşah,bu beyliğin topraklarına hakim olmuştur. ${ }^{44}$

\section{E - Çaka Bey}

Çaka Bey, Oğuzlar'ın Çavuldur boyundan olduğu sanılmaktadır ${ }^{45}$. Hakkında çok az bilgi bulunmaktadır. Elimizdeki bilgiler ise Bizans İmparatoru I.Alaeksiyos Komennenosun kızı Annan'ın kaleme aldığı Alakxiada adlı eserine dayanır ${ }^{46}$. Malazgirt Savaşı'ndan sonra Alparslan'ın emriyle Anadolu'ya yapılan akınlara katıldı. Çaka Bey, yaklaşık 1078-79 yılarında Türklerle Bizans arasında yaşana çarpışmaların birinde tecrübesizliğinin kurbanı olarak Bizans komutanı Aleksandros Kabalikos tarafından esir edildi. Asil ve itibarlı bir aileden geldiği için Bizans İmparatoru, Çaka Bey’e değerli armağanlar vererek kendisini "soyluların en birincisi” unvanıyla onurlandırmıştır. Çaka Bey, uzun süre İstanbul'da kaldıktan sonra buradan ayrıldı. İstanbul'dan tam olarak ne zaman ayrıldığı bilinmemektedir ${ }^{47}$. Bununla beraber Çaka'nın, İzmir'i nasıl ve ne zaman aldığına dair bilgi de yoktur ${ }^{48}$.

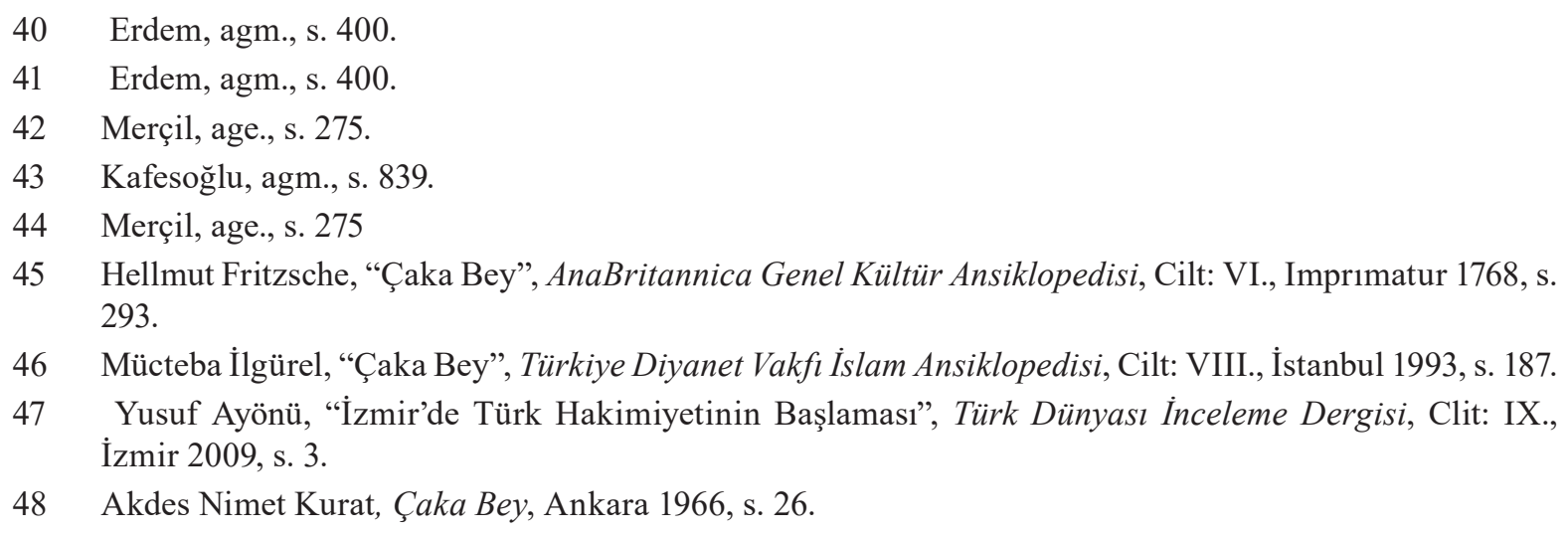
293.

46 Mücteba İlgürel, “Çaka Bey”, Türkiye Diyanet Vakfı İslam Ansiklopedisi, Cilt: VIII., İstanbul 1993, s. 187.

47 Yusuf Ayönü, “İzmir'de Türk Hakimiyetinin Başlaması”, Türk Dünyası İnceleme Dergisi, Clit: IX., İzmir 2009, s. 3.

48 Akdes Nimet Kurat, Çaka Bey, Ankara 1966, s. 26. 
Çaka Bey'e verilen bu kadar hediye ve ayrıcalıklara rağmen, İstanbul'u terk etmesinin nedeni ise İmparator Nikephoros Botaniatos tarafından verilen yetkiler, 1081' de Bizans tahtına geçen I.Aleksisos Komnenos tarafından alınmasıdır ${ }^{49}$. Anadolu'nun çeşitli yerleri Türk Beyleri tarafından işgal edilmesi, Bizans'ın, Anadolu ile bağlarını kesmişti. Bu firsattan yararlanan Çaka Bey, İzmir'i alarak ilk açık deniz donanmasını oluşturdu. Oluşturduğu bu donanma ile faaliyetlere başladı ${ }^{50}$. Çaka Bey'in aldığı şehir ve adaları geri almak için gelen Bizans orduları mağlup edildi. Bunun üzerine Bizans İmparatoru, Dalassenos komutasında daha güçlü bir donanma gönderdi. Denizde savaşmayı kabul etmeyen bu donanma, sakız adasında yapılan kara savaşında yenildi. Çaka Bey'in, bu başarıları Türklerin denizlerde de başarılar elde edebileceğini göstermiştir ${ }^{51}$. Çaka Bey'in, en büyük amacı, Bizans'a kesin bir darbe indirip, İstanbul'u fethetmek ve Bizans tahtını ele geçirmek idi. Bunun için Balkanlar'daki, Bizans için büyük tehdit oluşturan, Peçeneklerle temasa geçti. $\mathrm{Bu}$ durumdan haberdar olan I.Aleksios, Peçeneklere karşı bir diğer Türk Boy’u olan Kumanlarla anlaştı. 1091 yılında Peçenekleri, kadın ve çocuklar da dahil olmak üzere tamamını k1lıçtan geçirdi. Çaka'ya karşı da aynı politikayı izleyen I.Aleksios, Türkiye Selçuklu Sultanı I.Kılıçaslan'ın, Çaka Bey'i öldürmesini sağladı. 1097 yılı haziranında haçlı kuvvetleri sayesinde İznik'i alan Bizans, aynı yıl içinde İznik ve çevresindeki Türk hakimiyetine son verdi. Kara ve Deniz'de İzmir'i abluka altına alan Bizans orduları, Şehri aldılar ve büyük küçük demeden 10.000 kişiyi kılıçtan geçirdiler. Böylece İzmir'deki 17 yıllık Türk hakimiyeti çok stratejik bir şekilde son buldu ${ }^{52}$.

\section{F - Ebu'l-Kasım Bey}

Kaynaklarda, doğum tarihi ve kökeni hakkında bilgi bulunmamakla beraber, bir Türk Bey’i olduğu anlaşılmaktadır.Süleyman Şah 1084'te Antakya fethi için yola çıktığı vakit, İznik ve civarını Ebu'l-Kasım'a bırakmıştır ${ }^{53}$. Süleyman Şah'ın, seferde ölmesi üzerine Ebu'l-Kasım, kendisini sultan ilan etti ve kardeşi olan Ebül-Gazi'yi de Kapadokya emirliğine getirdi.

Yönetimi tamamıyla ele alan Ebu'l-Kasım, Marmara sahillerine akınlar düzenleyerek bütün Bithynia'yı yağmalamaya başladı. Bunun üzerine İmparator Aleksios, İznik üzerine, Türk asıllı Tatikos komutasında bir ordu gönderdi. Bizans ordusunun yola çıtığ 1 vakitlerde Melikşah da, Emir Porsuk komutasında 50 bin kişilik bir orduyu, İznik'i itaat altına almak için gönderdi. Bu orduyla baş edemeyeceğini anlayan Tatikos, İstanbul'a geri döndü. Ebu'l-Kasım bundan sonra da Kios (Gemlik) şehrini ele geçirdi. Aleksios, bu tehlikeyi bertaraf etmek için Manuel Boutoumites' in emrine bütün donanmasını vererek, Ebu'l-Kasım'ın donanmasını ortadan kaldırmakla görevlendirdi. Ayrıca karadan da Tatikos komutasında büyük bir ordu gönderdi. Bunu duyan Ebu'l-Kasım, Kios'dan ayrıldı. Kara yolunda Tatikos ordusuyla karşılaştı. Yapılan savaşta yenilen Ebu'l-Kasım, İznik'e güçlükle ulaşabildi. İznik önlerine gelen Porsuk, şehri muhasara altına aldı. Üç ay süren muhasarada Ebu'l-Kasım'ı çok zor durumda kaldı ve daha önce dostluk kurduğu Aleksios'dan yardım talebinde bulundu. İmparator, Peçeneklerle uğraştığı içi büyük bir ordu gönderemiyordu. Bunun için bir oyuna başvurarak, küçük bir kuvvetle imparatorluk alametlerini gönderdi. İznik'e gelen bu kuvvet, surların üzerinden imparatorluk sancağını ve alametlerini gösterdiler. Porsuk,

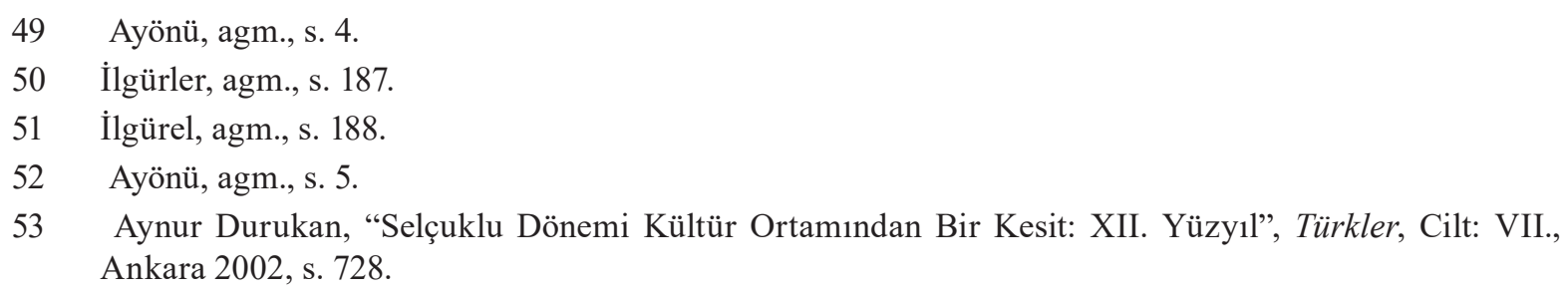


imparatorun bizzat geldiğini sanarak kuşatmayı kaldırdı. Porsuk'un başarısızlığı üzerine Melikşah, İznik' in zaptı için Emir Bozan'1 gönderdi. Bozan'ın teşebbüslerine karşılık, Ebu'l Kasım'ın, şiddeti müdafaası ve İmparatordan yardım alması sayesinde muhasara bir türlü netice vermedi. Ebu'lKasım, artık bağımsız hüküm sürme imkânının bulunmadığını fark etti. Bunun için Melikşah'a bağl1lık bildirmek ve İznik bölgesinde onun valisi sıfatıyla tasdik edilmeyi ümit ederek, İsfahan'a doğru yola çıktı. Ancak yolda Bozan'ın gönderdiği iki yüz kişilik bir kol asker tarafından yakalanarak kendi yayının kirişiyle boğduruldu $(1092)^{54}$.

\section{Sonuç}

Malazgirt Savaşı'ndan sonra Anadolu’ya gönderilen komutanlar, görüldüğü üzere, beyliklerini kurup bağımsız hareket etmeye başladılar. Türklerin, Anadolu'ya hızlı bir şekilde yayılmalarını sağladılar. Bunların kendi aralarındaki çekişmeleri, Bizans'ın iç işlerine karışması, güçlü birer devlet haline gelememeleri gibi sorunlar yaşamışlardır. Haçlı tehlikesi gibi tehditler dışında bir araya gelmemişlerdir. Kendi bölgelerinde bağımsızlıklarını tesis ederken birçok önemli güçle uğraşmak zorunda kalmışlardır. Ele geçirdikleri bölgeleri yurt haline dönüştürürken zorlanmadıklarını görmekteyiz. İdari, hukuki, eğitim, imar faaliyetlerinde çağının diğer oluşumları ile kıyaslandıkları vakit hiç de geride olmadıkları görülür. Anadolu'da birçok alanda ilk sayılabilecek birçok gelişme bu bağımsız yapılar sayesinde görülmüsstür. Anadolu'daki imar faaliyetlerinin önemli bir kısmı bu beylikler zamanında gerçekleşmiştir. Artuk Bey, Danişmend Gazi, Mengücek Gazi gibi beylerin sadece toprak kazanmak, sınır genişletmek derdine düşmedikleri anlaşılmaktadır. Onların her anlamda temel attıkları Anadolu coğrafyası, kendilerine tabi oldukları veya sonradan gelen Türk devletleri için birçok sorunun çözülmüş olduğu alanlara dönüşmüş ve fetihler için uygun ortamı oluşturmuştur.

\section{Kaynaklar}

Ayönü, Yusuf (2009). “İzmir’de Türk Hakimiyetinin Başlaması”, Türk Dünyası İnceleme Dergisi, Cilt: IX., Sayı: 1., Sayfa: 1-8, İzmir.

Durukan, Aynur (2002). "Selçuklu Dönemi Kültür Ortamından Bir Kesit: XII. Yüzyll”, Türkler, Cilt: VII., Sayfa: 726-728., Yeni Türk Yayınları, Ankara.

Erdem, İlhan (1999). "Doğu Anadolu Türk Devletleri”, Türkler, Cilt: VI., Sayfa: 385-390., Yeni Türk Yayınları, Ankara 2002EREN Mustafa, "Artuk Bey”, Görsel Büyük Genel Kültür Ansiklopedisi, Cilt: III., Sayfa: 858., Görsel Yayınları, İstanbul.

Fritzsche, Hellmut (1768). "Çaka Bey”, AnaBritannica Genel Kültür Ansiklopedisi, Cilt: VI., Sayfa: 293., Encyclopaedıa Britannica, INC., Imprimatur.

Fritzsche, Hellmut (1768). "Mengücek Gazi”, AnaBritannica Genel Kültür Ansiklopedisi, Cilt: XV., Sayfa: 570., Encyclopaedıa Britannıca, INC., Imprımatur.

İlgürel, Mücteba (1993). "Çaka Bey”, Türkiye Diyanet Vakfi İslam Ansiklopedisi, Cilt: VIII., Sayfa: 186-188., Diyanet Vakfı Yayınları, İstanbul.

Kafesoğlu, İbrahim (1976). "Ortadoğu'da Kurulmuş Türk Devletleri”, Türk Dünyası El Kitabı, Seri: I., Sayfa: 838-840., Türk Kültürünü Araştırma Enstitüsü Yayınları, Ankara. 

Ankara.

Kurat, Akdes Nimet (1966). "Çaka Bey”, Türk Kültürünü Araştırma Enstitüsü Yayınları,

Levent, Agah Sırrı (1964). “Çubuk”, Türk Ansiklopedisi, Cilt: XII., Sayfa: 136., Milli Eğitim Basımevi, Ankara.

Merçil, Erdoğan (2011). Müslüman -Türk Devletleri Tarihi, TTK Basımevi, Ankara.

Merçil, Erdoğan(2002). “Türkiye Selçukluları”, Türkler, Cilt: VI., Sayfa: 505-507., Yeni Türkiye Yayını, Ankara.

Nur, Rıza (1924). Türkiye Tarihi, Cilt: IV., Tokat Yayınları, İstanbul.

Özaydın, Abdulkerim (1993). "Danişmend Gazi”, Türkiye Diyanet Vakfi İslam Ansiklopedisi, Cilt: VIII., Sayfa: 467-469., Diyanet Vakfi Yayınları, İstanbul.

Öztuna, Y1lmaz (1977). Büyük Türkiye Tarihi, Cilt: I., Ötüken Yayınları, İstanbul.

Öztuna, Yılmaz (1989). “Devletler ve Hanedanlar”, Türkiye 1074-1990, Cilt: II., Sayfa: 48., Kültür Bakanlığı Yayınları, Ankara.

Sevim, Ali (1991). “Artuk b. Eksuk”, Türkiye Diyanet Vakfi İslam Ansiklopedisi, Cilt: III., Sayfa: 414-415., Diyanet Vakfı Yayınları, İstanbul.

Solmaz, Sefer (2002). “Danişmendliler”, Türkler, Cilt: VI., Sayfa: 430-438., Yeni Türkiye Yayınları, Ankara.

Sumer, Faruk (1993). "Mengücekliler”, Türkiye Diyanet Vakfi Íslam Ansiklopedisi, Cilt: XXIX., Sayfa: 138-142., Diyanet Vakfı Yayınları, İstanbul.

Tellioğlu, İbrahim (2004). Osmanll Hakimiyetine Kadar Doğu Karadeniz'de Türkler, Serander Yayınları, Trabzon.

Turan, Osman (2011). Selçuklu Tarihi ve Türk-İslam Medeniyeti, Ötüken Yayınları, İstanbul. 